\title{
ANALYSIS OF LANGUAGE SKILLS IN PRIMARY SCHOOL CHILDREN (STUDY DEVELOPMENT OF CHILD PSYCHOLOGY OF LANGUAGE)
}

\author{
Dida Firmansyah \\ STKIP Siliwangi \\ dfirmansyah86@gmail.com
}

\begin{abstract}
The skills and development of children's language are unique to observe, the researchers found several cases of varying language abilities in the age range of 6-12 years old who are still in primary school. From the perspective of child development psychology, the findings are influenced by several factors that are directly or indirectly related to the child's life. On the basis of this background, the researchers made an analysis of the results of observation of primary school children in the age range of 6-12 years with the object of research made randomly. The result of the data obtained by the researcher is that the elementary school age children have significant differences in the ability to speak in the school environment and outside the school environment.
\end{abstract}

Keywords: Analysis, Language Skills, Primary School

\section{INTRODUCTION}

The matter of this research is based on the diversity of the initial ability of elementary school students in the school environment, it is much influenced by the family environment, the community where the child lives. Many researchers conducted empirical observations in the field so that it was considered unique from various aspects of elementary school age children. The community where a primary school-age child life is mixed on many factors that influence the abilities and thinking skills of these elementary school-age children. Family and the variety of ways and speaking styles of family members influence many children's skills and communication skills even though family factors are only one of many influencing factors. The community of communication and ethnic diversity in terms of sociolinguistics is the strongest influence to shape the abilities and speaking skills of an elementary school child.

Children in their development will receive a lot of stimulation directly or indirectly during their growth in the age range of 6-18 years (Syaodih, 1995). Some aspects that affect children's development include physical development, psychology and the ability to interact socially in their environment. In the age range of 6-18 years, children feel they need information from other people around who not only have family relationships, but they also want a lot of interaction with other people outside the family environment. For example, in 
the surrounding community and children's school, they will receive influences from various different aspects and goals, from the influence of attitudes, speech styles, vocabulary additions, and attitudes.

Human character has been attached to a person's personality and shown in the behavior of his daily life. Since birth, humans have had the potential of character that is shown by their cognitive abilities and innate traits. Innate characters will develop if you get a touch of learning experience from the environment. The family is the first learning environment that children get and will be a strong foundation to shape character after adulthood. The results showed that around $50 \%$ of the variability of adult intelligence had occurred when a child was four years old. The next $30 \%$ increase occurs at the age of eight years, and the remaining $20 \%$ in the middle or end of the second decade (Suyanto, 2010). The development of intelligence is accompanied by mental development of other personalities until adolescence. After adulthood, intelligence and personality behavior has been relatively stable, therefore if you want to form intelligence and character, the most appropriate time is at the age of children to adolescents.

Children's language skills in their development can be seen and assessed directly from the child's speaking ability in various social situations, because it is very possible that there are different ways and styles of speaking for different situations and interlocutors. The speaking skills referred to by the researcher are a language skill that develops in a child's life, which is only preceded by listening skills, and at that time the ability to speak or speak is learned (Tarigan, 1987). Many things are related to language development in children, especially with regard to language development in elementary school-age children which includes (1) the nature of language development; (2) children's language development; (3) development of oral communication; (4) development of written communication; and (5) the development of reading and writing (Slamet, 2008).

The external influence factor is only one side of the forming factor of ability and speaking ability, but not only that factor. There are also internal factors related to the psychological factors of elementary school children. Like, the ability of utterances, intuition, and pressure from various external factors. From various reasons for thinking, the authors formulated several things to analyze, namely, how the influence of children's development skills in the 
environment can shape abilities that are considered unique for elementary school-age children. Early childhood analysis activities aim to allow special stimulation, treatment and treatment to be provided that can maximize the skills and verbal communication skills of elementary school-aged children.

Psychologically there are several factors that influence the development and change of character in children. The two main factors that can affect children's development include genetic factors and external factors or the environment in which the child grows (Kartono, 2007). Genetic factors, namely things that are inherited from parents and that are permanent or not will change significantly during the child's development, such as race, hair, eyes and physical growth that will not be different from their parents. Meanwhile, external or environmental factors are things that affect children significantly and cannot be limited to changes, which include family, peers, life experiences in the environment and health.

Language skills are access to direct communication in the community in a variety of environments that allow the emergence of a complex and sustainable social atmosphere (Susanto, 2016). Indeed, it is undeniable that communication skills are always changing and relatively developing, adjusting the talk page. This is similar to the statement of Slamet (2008) regarding language skills always giving and getting influence from several factors, in this case, external and internal factors in human psychology.

The age of elementary school children is the best time to form language characters in children from the age of middle school children or the age of teenagers. Primary school teachers must have new references that are more accurate in shaping the character of children's language skills by applying diverse and continuously developed learning theories (Susanto, 2016). Teachers must have the ability to understand the development of elementary school-age children with several aspects of the review, which include physical and motoric character of children, development of perceptions, the character of language development, development of independence and career development of elementary school-age children (Budiman, 2006). From the theoretical statement, the researcher obtained several keywords to provide communication stimulation in elementary school children by reviewing several aspects of 
genetic development of children, external factors and the strength of the role of teachers to improve language skills in children.

Schools as formal education institutions often become role models in various ways including role models in educating characters. Character education in schools is adjusted to the age level of students' mental development. Suyanto (2010) agrees that character formation and development has occurred until adolescents are teenagers. Once mature, the character possessed by humans is relatively stable and permanent. Therefore, the character education model at the age of children, adolescents and adults cannot be equated. One model of character education that is effectively applied in elementary schools is not necessarily effective for adolescents and adults. This study aims to analyze effective character education models at the age of children, adolescents, and adults that have been carried out in elementary, middle and high school through the study of relevant research results and school programs. This study is expected to benefit the development of a new character education model that is feasible for different target audiences. Gardner suggests the concept of multiple intelligences or multiple intelligences that can distinguish learning tendencies and interests that someone has with others. According to Gardner, multiple intelligence has several aspects, namely: (1) logical mathematical intelligence (2) visual / spatial intelligence (3) body kinestets intelligence (4) musical / rhythmic intelligence (5) verbal / linguistic intelligence (6) interpersonal intelligence (7) intrapersonal intelligence and (8) naturalistic intelligence.

\section{Formulation of The Problem}

The researcher formulated the problem to make it easier to find and obtain the data needed in the study, namely by formulating a problem regarding the speaking skills of children aged 6 12 who are still in elementary school, how the different characters of language used by children aged 6 - 12 influenced by friends in and outside the school environment.

\section{Research Purposes}

Each study always has a goal so that the results of the study are more directed, in this case, the researcher formulates several research objectives which include speaking skills of children aged 6 - 12 years. Analyzing the character differences in children's language skills in the age range of $6-12$ years and Analyzing the effects of the school and outside school environment on the speaking skills of children aged $6-12$ years. 


\section{METHOD}

The process of analyzing this research is carried out using the descript method, namely the use of research methods to collect observations from data obtained in the field by presenting findings and explaining the analysis carried out by researchers (Sukmadinata, 2007). The object of the research used was elementary school students aged $6-12$ years who were deliberately stimulated to talk about personal experiences directly without scenarios by researchers. Analysis of the initial characteristics of students is one of the efforts made to gain understanding about; demands, talents, interests, needs, and interests of students, related to a particular learning program. This stage is deemed so necessary to remember many considerations such as; students, social development, culture, economy, science and technology, and the interests of certain educational / learning programs that students will follow.

\section{RESULTS AND DISCUSSION}

In this study, researchers obtained results regarding data on children aged 6 - 12 years in the elementary school environment with random or unspecified sex selection. The researcher analyzed 5 elementary school students by communicating directly in the school environment and 5 elementary school students by communicating outside the school environment. So overall researchers use 10 elementary school students as the object of research. The researcher obtained data on the communication skills of elementary school children from various aspects, first the emotional aspects of the interlocutor, the types of games performed by the child and the pattern of education in school for a child.

Character education has been integrated into Indonesian language subjects through media illustrated stories and role-playing methods. Character education has also been integrated into elementary school learning through character-based learning models and methods carried out by a teacher. The results showed that the use of models and methods of effective character education to improve the practice of politeness, honesty, patience, and adherence to community norms, as well as Indonesian language skills (listening, reading and speaking).

Analysis of the 10 research objects is that elementary school students who are stimulated to communicate with researchers in two different environments will prove differences in 
speaking styles with differences in vocabulary used by children aged $6-12$ years to communicate that are distinguished from the economic abilities of parents, adult dominance in the child's life and the family's communication environment.

\section{DAFTAR PUSTAKA}

Ahmad Susanto, M. P. (2016). Teori Belajar dan Pembelajaran di Sekolah Dasar. Kencana.

Budiman, N. (2006). Memahami Perkembangan Anak Usia Sekolah Dasar. Jakarta: Departemen Pendidikan Nasional.

Kartono, K. (2007). Psikologi Perkembangan Anak. Jakarta: Erlangga.

Slamet, S. Y. (2008). Dasar-Dasar Keterampilan Berbahasa Indonesia. Surakarta: LPP UNS dan UPT Penerbitan dan Percetakan UNS.

Sukmadinata, N. S. (2007). Metode Penelitian. Bandung: PT Remaja Rosdakarya.

Suyanto. (2010). Urgensi Pendidikan Karakter. diunduh tanggal 1 Maret 2010 dari Www.kemendiknas.go.id

Syaodih, E. (1995). Psikologi Perkembangan. Journal of Chemical Information and Modeling. Bandung: Mandar Maju. https://doi.org/10.1017/CBO9781107415324.004

Tarigan, H. G. (1987). Berbicara sebagai Suatu Keterampilan Berbahasa. Bandung: Angkasa. 